\title{
Gender differences in emotional maturity among urban adolescents
}

Received: 21.06.2018; Revised: 16.11.2018; Accepted: 29.11.2018

See end of the paper for authors' affiliations Shiksha Rani

Department of Human

Development and Family Studies, College of Home Science, Punjab Agricultural University, Ludhiana (Punjab) India
ABSTRACT : The present research was conducted to study the gender differences in emotional maturity. In the present study, a sample of 100 students (50 boys and 50 girls) in the age group of 16-18 was drawn from the Govt. Higher Secondary School of Ludhiana city. Emotional Maturity Scale (Singh and Bhargava, 1990) was used to collect data. Overall results indicated that both boys and girls were emotionally unstable. In comparison to girls, boys were found to be more emotionally mature than girls.

KEY WORDS: Gender differences, Emotional maturity, Adolescents, Schools

- HOW TO CITE THIS PAPER : Rani, Shiksha and Kanwar, Vandana (2018). Gender differences in emotional maturity among urban adolescents. Asian J. Home Sci., 13 (2) : 654-656, DOI: 10.15740/HAS/ AJHS/13.2/654-656. Copyright@ 2018: Hind Agri-Horticultural Society. 